\title{
Pricing Decision of Green Tea Leaves Produced by Small Tea Growers in Golaghat District of Assam
}

\author{
Anitabh Kakoty* and Ratan Kaurinta \\ Department of Commerce, Nagaland CentralUniversity, Meriema, Kohima Campus, India \\ *Corresponding author: anitabh76@googlemail.com (ORCID ID: 0000-0002-0827-1644)
}

Received: $20-09-2021$

Revised: 26-11-2021

Accepted: 16-12-2021

\begin{abstract}
The present study has a focus on the pricing decision of green leaves which is interlinked with different stages of marketing. The small tea growers of Golaghat district of Assam has grown rapidly from the 1990s due to various stimulus present in the tea market. It is viewed that the small tea growers in Assam is almost 15000 in numbers produce only green leaves which is the basic raw material for tea. The green leaves price is dependent on the bought leaf factories decision, role of collection agents and estates factories price fixation, and it is seen that small tea growers are a price taker. The price of the small tea growers is also impacted by its quality and various agro-climatic, agronomic, and pricing formulas. The correlation of prices of tea in different forms in different markets has shown a good degree of importance now a days. However, the price of tea as green leaves is being seriously affected by the rising cost of inputs. The study has recommended for the better quality of tea to gain good price which starts with fine plucking which should be accompanied by orientation towards organic with a lesser degree of absorption of soil with optimal management of tea bushes.

\section{HIGHLIGHTS}

(0 Price of tea has a significant link to the agro climatic, agronomic and pricing formulas.

0 The Bought Leaf factories, Large estate factories and Collection agents are together price fixers for green tea leaves.

(0) The quality of tea leaves which is a strong determinant for price fixation is significantly linked to plucking methods.
\end{abstract}

Keywords: Pricing decision, marketing, small tea growers, pricing formulas, bought leaf factories, collection agents

Pricing decision in "Tea Industry" has become a complex mechanism in present situation. Tea as a beverage has an indispensable place in the society of the world. It is a start up drink for a good number of households. Assam has a prominent place among the regions which produces tea and Assam's tea is well known for its strong liquor blend. Assam has a geographical tagging for tea production with definite quality and known tea producer (Biggs et al. 2018). Though processed tea finally comes out from manufacturing unit in the form of CTC (Crush, Tear, Curl), orthodox and different variants of blends. The production of processed tea is dependent on its sole raw material famously known as" Green Tea Leaves". The dynamics behind pricing of green leaf is interlinked to various factors ranging from farmers own decision as well as supply channels which connects the end product to the auction market and export markets. A micro level lens could trace out the price of tea as a phenomenon which depends on the interaction between the cultivators, estate owners, bought leaf factories

How to cite this article: Kakoty, A. and Kaurinta, R. (2021). Pricing Decision of Green Tea Leaves Produced by Small Tea Growers in Golaghat District of Assam. Economic Affairs, 66(04): 685-690.

Source of Support: None; Conflict of Interest: None (c) 9 
or standalone factories and various stakeholders in different markets domestic as well as export market. The trajectory of the Small Tea Growers green leaf supply which reaches the end consumer after different processes can be viewed with the aid of the flow diagram as follows in fig. 1 :

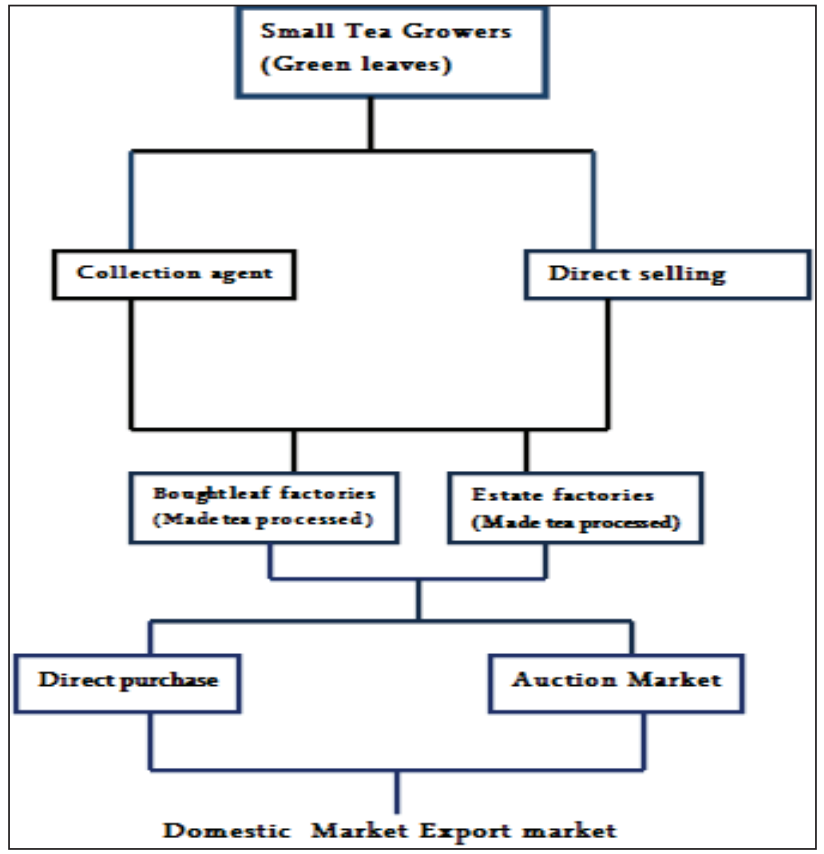

Fig. 1: Flow chart diagram of tea market

Small tea growers are layered in terms of dependency on decision making and work as a subcontractors with dependence on favourable climate for yield and as a price receiver from bought leaf factories,large estates and multinational companies at the top of the ladder (Sharma et al. 2017).

The study has a focus on pricing decision of green leaves produced by "small tea growers" more popularly known as STGs which has an acreage of below 10.12 has in Golaghat district of Assam demarcated by geographic region of $26.3185^{\circ} \mathrm{N}$, $94.0907^{\circ} \mathrm{E}{ }^{0} \mathrm{~N}$. The Golaghat district is pioneer in production of tea in small holdings during the post colonial period characterized by available uplands with conducive agronomical and economic conditions. According to Tea Board of India, the apex regulatory body for tea cultivation, the district have over 6000 registered STGs which are mostly unorganized and they have a umbrella organization known as All Assam Small Tea Growers Association(AASTGA). Moreover, the motivation of entrepreneurship and "tea" as a perennial cash crop lured the people to embrace this cultivation. The study has been conducted with an objective :

(i) To evaluate the situation of price mechanism in case of STGs of Golaghat district in Assam

(ii) To assess the relationships of tea price movement in different markets in different form.

\section{MATERIALS AND METHODOLOGY}

The study has a concentration on the pricing decision of green tea leaves of STGs and the district of Golaghat in Assam is demarcated by $26.3185^{\circ} \mathrm{N}$, $94.0907^{\circ} \mathrm{E}{ }^{0} \mathrm{~N}$ in the North East part of India. The survey was conducted by using multistage sampling for 120 samples drawn from STGs, collection agents, employees of bought leaf tea factories and large tea estates. The price of tea in different markets is taken for study are export market price (EXP), tea auction price in Guwahati tea auction market (GAP), Indian auction market price (IAP), small tea growers price (STGPRI) and wholesale price index of tea (WPIT). Where STGPRI is the price for the green leaves and EXP, GAP, IAP and WPIT are the prices for the processed tea. For secondary data sources, reports of Tea Board of India and Statistical Handbook of Assam is utilized.

\section{RELATIVE CHANGES AND PRICE INDICES}

\section{Jevons Index}

$$
P_{0: t}^{J}=\prod\left(\frac{p_{t}^{i}}{p_{0}^{i}}\right)^{1 / n}=\frac{\prod\left(p_{t}^{i}\right)^{1 / n}}{\prod\left(p_{0}^{i}\right)^{1 / n}}
$$

\section{Carli Price Index}

$$
P_{0: t}^{C}=\frac{1}{n} \sum\left(\frac{p_{t}^{i}}{p_{0}^{i}}\right)
$$

The results obtained for price movements in different markets for tea in different forms can be interpreted by using Jevons index which is the geometric mean of prices and Carli price index which shows arithmetic mean of price ratios where the average price of tea for the year of 2010 is considered as Base Year price. 


\section{Correlation Matrix And Standard Deviation}

Correlation matrix is utilized to find out the relationship among the prices of tea along different markets in different forms. The correlation matrix has a strong role to play in determining pair wise degrees of relationship between different components of a random vector which is important in case of multivariate analysis (Pham-Gia et al. 2014). Standard deviation of tea price in different market is calculated. The standard deviation (SD) measures the dispersion considered as a index of variability related to original data points which is mentioned in most studies (Streiner, 1996).

\section{RESULTS AND DISCUSSION}

The results of price of tea can be viewed as a result interaction between the price of tea in different markets in different forms ranging from basic raw material or green tea leaves market to the processed tea market meant for end consumers as shown in Table 1.

In Table 2, both the price indices are drawn using Carli and Jevons index, taking 2010 as Base year for price of tea. It was observed that from 2010 to 2011, it was a slight change of price with an increase of 4 to 5 percent. But from $2012-2018$, the price rise is in the bracket of 20 to 30 percent as compared to the base years.

Table 1: Price of tea in different markets in different forms

\begin{tabular}{|c|c|c|c|c|c|}
\hline Year & IAP & GAP & EXP & STGPRI & WPIT \\
\hline 2009 & 106.7 & 122.9 & 140 & 12 & 179 \\
\hline 2010 & 106.32 & 112.93 & 137 & 12 & 147.38 \\
\hline 2011 & 106.07 & 108.47 & 152 & 14 & 150.6 \\
\hline 2012 & 125.25 & 131.01 & 180 & 17 & 184 \\
\hline 2013 & 132.23 & 132.55 & 198 & 14 & 135.4 \\
\hline 2014 & 130.91 & 139.41 & 195 & 17 & 120 \\
\hline 2015 & 128.6 & 138.64 & 190 & 15 & 116.2 \\
\hline 2016 & 134.26 & 137.51 & 200 & 16 & 137.8 \\
\hline 2017 & 133.11 & 140.73 & 197 & 13 & 133.5 \\
\hline 2018 & 137.65 & 149.33 & 204.47 & 14 & 138 \\
\hline 2019 & 196.97 & 139.73 & 226.85 & 13.5 & 139.5 \\
\hline
\end{tabular}

Note: Tea Board of India, Statistical Handbook of Assam \& Guwahati Tea Auction Centr.

The major rise that could be seen was in the year of 2019 where both the indices shows a rise of over 40 percent in price index.

Table 2: Price indices of tea in different markets

\begin{tabular}{|c|c|c|c|c|c|c|c|c|c|c|}
\hline Item $\backslash$ Year & 2010 & 2011 & 2012 & 2013 & 2014 & 2015 & 2016 & 2017 & 2018 & 2019 \\
\hline IAP & 1 & 0.99 & 1.17 & 1.24 & 1.23 & 1.20 & 1.26 & 1.25 & 1.29 & 1.85 \\
\hline GAP & 1 & 0.96 & 1.16 & 1.17 & 1.23 & 1.22 & 1.21 & 1.24 & 1.32 & 1.23 \\
\hline EXP & 1 & 1.10 & 1.31 & 1.44 & 1.42 & 1.38 & 1.45 & 1.43 & 1.49 & 1.65 \\
\hline STG PRI & 1 & 1.16 & 1.41 & 1.16 & 1.41 & 1.25 & 1.33 & 1.08 & 1.16 & 1.12 \\
\hline $\begin{array}{l}\text { Geometric average } \\
\text { of price relative }\end{array}$ & 1 & 1.04 & 1.25 & 1.24 & 1.31 & 1.25 & 1.30 & 1.24 & 1.30 & 1.43 \\
\hline Jevons Index & 100 & 104 & 125 & 124 & 131 & 125 & 130 & 124 & 130 & 143 \\
\hline $\begin{array}{l}\text { Arithmetic average } \\
\text { of price relative }\end{array}$ & 1 & 1.05 & 1.26 & 1.25 & 1.32 & 1.25 & 1.31 & 1.25 & 1.31 & 1.48 \\
\hline Carli Index & 100 & 105 & 126 & 125 & 132 & 125 & 131 & 125 & 131 & 148 \\
\hline
\end{tabular}

Table 3: Correlation matrix table of different tea prices from 2009-2019

\begin{tabular}{llllll}
\hline Pearson Correlation & IAP & GAP & EXP & STGRI & WPIT \\
\hline IAP & 1 & .616 & .849 & .114 & -.310 \\
GAP & .616 & 1 & .856 & .363 & -.455 \\
EXP & .849 & .856 & 1 & .411 & -.521 \\
STGRI & .114 & .363 & .411 & 1 & -.148 \\
WPIT & -.310 & -.455 & -.521 & -.148 & 1 \\
\hline
\end{tabular}

*Correlation is significant at the 0.05 level (2-tailed); ${ }^{* *}$ Correlation is significant at the 0.01 level (2-tailed). 
Table 4: Mean and Standard Deviation in Tea Price in different markets

\begin{tabular}{lll}
\hline Item (2009-2019) & Mean & Standard Deviation \\
\hline STG's Price in Golaghat (STGPRI) & 14.38 & 1.76 \\
Guwahati Tea Auction Price (GAP) & 132.11 & 12.51 \\
Indian Auction Price (IAP) & 130.73 & 25.04 \\
Export Unit Price of tea (EXP) & 183.66 & 28.66 \\
\hline
\end{tabular}

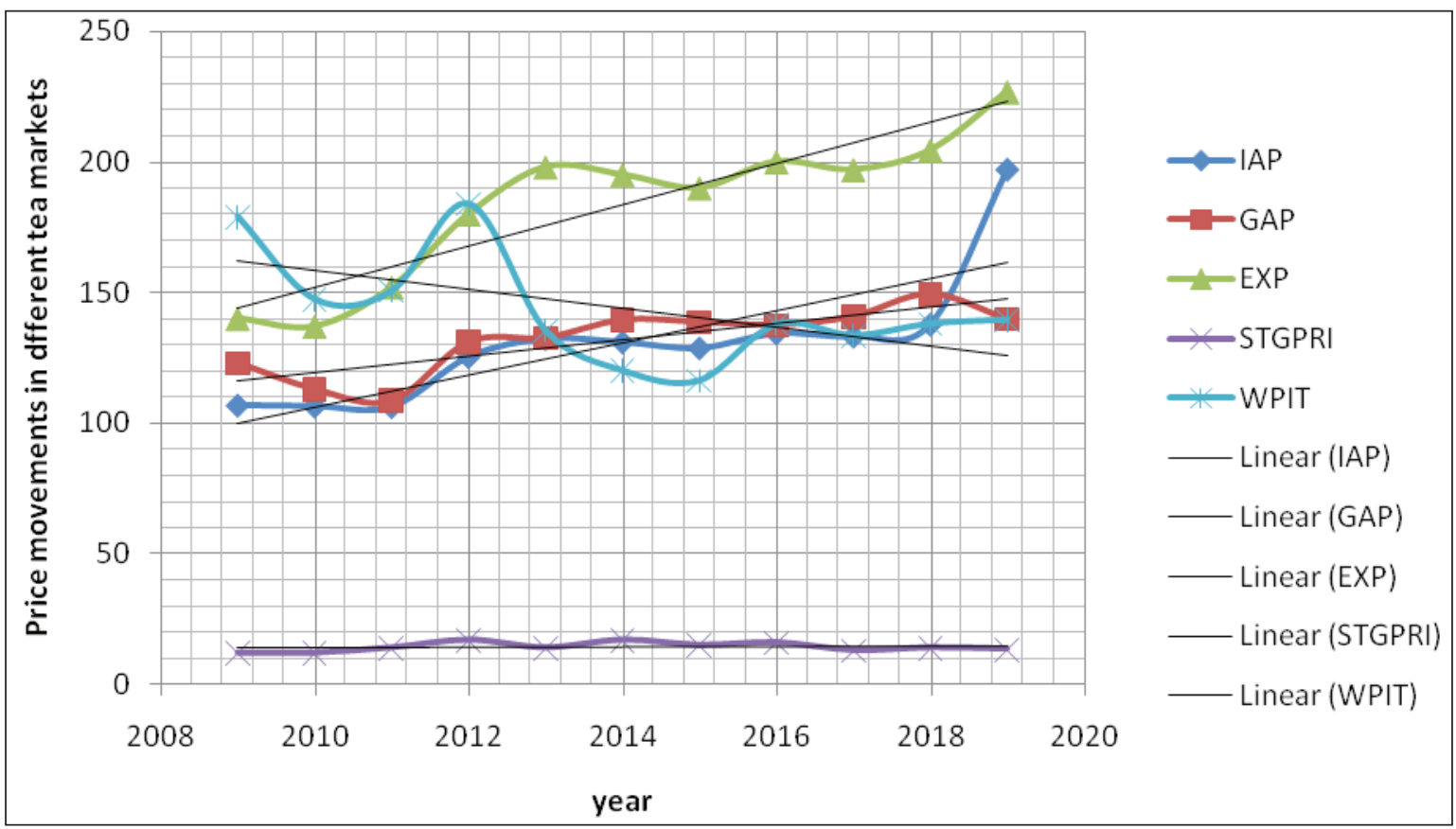

Fig. 2: Price movements across different tea markets (2009-2019)

Indian tea is mostly sold through the auction market of which almost 80 percent is placed in the internal market and the processed tea in Assam at a greater quantity is being auctioned through GTAC or Guwahati Tea Auction Centre which strongly indicates the demand and determines price and quantity along with Indian auction price. It is found that export market price is important as per normal perception states that it could garner a good price which can contribute to the for ex reserves of a country which may have a resultant effect on the green leaves price and quantity demanded. In this study, a correlation matrix is drawn in between Indian Auction price (IAP), Guwahati Auction Price (GAP), Export price (EXP), Small tea growers green leaf price (STGPRI) of Golaghat district and Wholesale Price Tea (WPIT). In Table 4, the standard deviation for the period of 2009 -2019 shows a diversion in price of IAP,GAP, STGPRI and EXP found to be 1.76, 12.51, 25.04 and 28.66. The low standard deviation for STG's per unit price means that it is not gaining in terms of price, of the made tea in Indian auction market, Guwahati auction market price and in terms of wholesale price of tea which has a higher standard deviation for their prices for tea. In Table 3, the correlation score between Indian auction price and STG's price at Golaghat district is not significant. But Guwahati Tea Auction price (GAP) has a low correlation score with STG's price of Golaghat (STGPRI). At the same time, although export price (EXP) has a moderate score of correlation with STG's price (STGPRI), it is not significant and WPIT of tea which is the index for made tea has no correlation with STG's price (STGPRI).

\section{Price Mechanism of Small Tea Growers}

Price mechanism of tea is waved by various factors which is largely dependent on the status of organization, role of leaf agents, existence of pricing formulas, quantity issues of tea leaves, price movements of tea and the role of Tea Board of India. STGs sell product to the factories through three 
different channels which involves direct selling to the factory; Secondly, through collection agents and thirdly, through involvement of middleman (Kalita, 2014). Organizational status of STG's do not make them capable to detect market signals pertaining to price as there is a distinct gap in relationship between the price fixing bodies and marginal farmers). The small tea growers product market has taken the characteristics of monopsony when a handful of big companies has become a price fixer through control of secondary processing of blending and packaging (Dave, 2016). In the tea market, leaf agents plays a dominant role as a principal means of marketing channel in determining price of green leaves. The agent has a strong cartel arrangement with Bought Leaf Factories and Estate factories. The study on the sale practices for processed tea is taking place through auction and direct sale (Saji, 2013). The TMCO or Tea Marketing of Control Act 2003 has directed to sale the 75 percent of made tea through auctions which reduces time and increases competition. Price of tea faces three different types of movements-cobweb, dumped and damped movements due to certain lag between price and supply (Himanshu, 1968).

The Tea Board of India has experimented with different pricing formulas in different formats known as Price Stabilization Fund (PSF), Price Tagging Formula and Minimum Benchmark Price (MBP). The PSF or Price sharing formula was practiced till 2012 which was determined on the basis of a "Price Spectrum Band" where a sum is credited to the farmers during distress period whereas in boom and normal period, the farmers need to contribute to the fund. The fund was built up as a shock proof measure with an intention of not to increase uncompetitive inefficiency. A band was determined with seven years moving average method for international crops for $+/-20 \%$ to reach a price spectrum band. Under tagging of STG's and BLF's, BLF's can purchase the green leaves from the STG's and STG's can sell their product to their tagged BLF's only. Under MBP or Minimum Benchmark Price mechanism which is a method, the price is fixed on the tea production and previous months auction rates. The quality of tea leave has a strong impact of pricing as quality is assessed per month through manual method and based on discretionary observation as the machinery for assessing the quality of green leaves is absent. Price movements of tea mainly undergo through different phases of pricing decision which effects the decision in different marketing channels and structures. The demand for tea is normally effected by Political, Economic, Social, Legal and Technological (PESTEL) forces prevalent in the market. In the matter of fair pricing of STG's green leaves with TMCO, 2003 is in practice which is Tea Monitoring and Control Order, the business information should be made transparent starting from tea growers to processing factories but in reality, it is suffered by low web. Tea Board of India's regional reporting is also inadequate where a number of small tea growers are out of sphere of influence on control. Due to this information asymmetry, the price performance of small tea growers is not optimal. The cost of cultivation has a strong impact on price of tea leaves as the break-even point for a small tea farmer is normally reached in the seventh year of plantation. The trend shows that from 2011-2019, the operation cost has increased by $115 \%$, material cost went up by $112 \%$ and other non recurring costs increases by $50 \%$ on an average which clearly increases the cost burden on STG's. Agricultural factors such as total harvest price, price of competitive items and extent of cultivation along with fertilizer chemicals works as an explanatory variables which has direct relationship in shaping the production as well as price elasticity of supply (Dayani et al. 2016).

Processed tea market is on the other hand are of three types where export market is based on forward market and the other two being auction market and direct purchase market. The worldwide value of tea is more important than its volume of production and exports (Asopa, 2007). Although India is ranked among the top five producers, the 90 percent of product is consumed in home market and in export market. The Indian tea has strong inclination for sale in the domestic market and only 10 percent of total tea grown in India is exported (Dhakre, 2015) India faces stiff competition from China, Kenya and Srilanka where the gain in terms of foreign exchange is high. The one of the reason of competition in the export market is the growing demand for orthodox and black tea variants in which India is lagging as it has more inclination towards production of CTC tea. 


\section{CONCLUSION}

Small tea growers pricing decision on green leaves on a strict price band decided by the cartel of BLF's, collection agents and large tea estates factories. The present structure of STG's do not have a stronger bargaining power due to its weaker organizational formation and at the same time information asymmetry of pricing is intense. The movement in the different auction markets, export markets and wholesale price of tea index has weak linkage to any price change which shares a very low standard deviation in yearly average price of green leaves in Golaghat district. The wide gap on pricing decision between the buyer's (BLF's, LE's, agents) and sellers (STG's for green leaves) makes any support price or regulatory price redundant. Though the district monitoring committee for minimum price is formed by the Tea Board of India, it has very weak control on green leaves price which has failed to provide realistic pricing for STG's. TMCO of 2003 is being amended time to time, but the balance of power is not established. The growing cost over the last decade from 2009-2019 has lowered the profitability of STG's which is accompanied by low working capital formation. The continuous failure in gaining price can create a crisis in the small tea growing sector and in some places of Assam, STG's are in exit mode. It can also be recommended based on this study that STG's should try organic, practice of quality plucking which is also known as "fine plucking" of tea leaves and form some strong and effective self-help group.

\section{REFERENCES}

Asopa, V.N. 2007. “Tea Industry of India, The cup that cheers has Tears" IIM Ahmedabad working paper.

Biggs M.Eloise, Gupta, Niladri, Saikia, D., Duncan M.A. John. 2018. The tea landscape of Assam: Multi stakeholders insight into sustainable livelihoods under a changing climate. Env. Sc.e and Policy, 82: 9-18.
Boselie, D. 2019. “The True Price of Tea from Kenya” Joint Report by IDH and True Price.

Dhakre, D.S. 2015. “National Trends on Agricultural Crop (Tea) Production and Export: A Statistical Analysis. Int. J. Bio-res. Env. Agril. Sci., 1(1): 39-44.

Directorate of Statistics and Economics 2019. Statistical Handbook of Assam. https://des.assam.gov.in/portlets/ statistical-handbook

Gunathiaka, Dayani R.P. and Tularam, A. 2016. “Tea Industry and a Review of its Price Modelling in Major tea Producing Countries". J. Mgt. and Strategy, 7(1).

Liu, H. and Shao, S. 2016. “India's Tea Price analysis based on ARMA Modelling". Modern Eco., 7: 118 -123.

Kadavil, and Saji, M. 2019. “The Indian tea Research”. https:// www.somo.nl/wpcontent/uploads/2007/01/Indian-TeaResearch.pdf.

Kalita, Kumar, Poresh. 2014. "Production Performance and Problems of Marketing of the Small Tea Growers in Assam". Ph.D Thesis. Shodhganga @INFLIBNET.

Roy, H. 1968. "Tea Price Stabilization-The Indian Case”. The World Press Pvt. Ltd.

Pham-Gia Thu et al. 2014. Distribution of the Sample Correlation Matrix and Applications. Open J. Statistics, 4: 330 -344.

Sarma, K., Chandan and Baruah, P. 2017. Small Tea Plantation and its Impact on the Rural Landscape of Contemporary Assam. Int. J. Rural Mgt., 13(2): 140-161.

Streiner, D.L. 1996. Maintaining standards: differences between the standard deviation and standard error, and when to use each. Can. J. Psychiatry, 41: 498-502.

Tea Board of India 2020. Annual Reports. http://teaboard.gov. in/TEABOARDPAGE/ODA=

Guwahati Tea Auction Centre, 2021. http://assamteaxchange. $\mathrm{com} /$ 